Teksty Drugie 2015, 1, s. 112-134

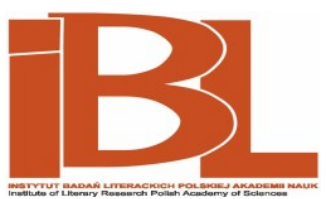

\title{
From Global to Alter-Globalist Art History
}

Piotr Piotrowski 
Piotr Piotrowski

\section{From Global to Alter-Globalist Art History'}

DOI: 10.18318/td.2015.en.1.8

\section{Does Global Art History Exist?}

Kitty Zijlmans begins her short but condensed programmatic article with the following words: "Clearly, art history is not global"2. After making this categorical statement, the author presents over a dozen points of her art-historical research programme which could be the response to the processes taking place in the world, including the global dimension of art culture. I will not summarise it here but I would like to note that, partially, it has a "level-headed" character. Her primary postulate to make it an "intercultural" project is compatible with the mainstream literature which has been increasingly published in the recent years. Some of her more interesting

1 The present article is an extended version of the paper presented at the Methodological Seminar organised by the Art Historians Association in Nieborów on October 25-27, 2012. I would like to thank Prof. Maria Poprzęcka for the consent to this publication which precedes releasing the volume of materials from the Seminar. Also, I would like to thank participants of a seminar I conducted in the 2012/2013 winter semester entitled Global Art History at the Warsaw University within the "modern university" project, for stimulating discussions.

Kitty Zijlmans, An Intercultural Perspective in Art History: Beyond Othering and Appropriation in Is Art History Global, ed. James Elkins (New York: Routledge, 2007), 289.

\section{Piotr Piotrowski}

- professor in the Institute of History of Art at the Adam Mickiewicz University in Poznań. Director of IHS UAM (1999-2008) and the National Museum in Warsaw (2009-2010). Visiting professor in inter alia the Bard College, USA (2001), the Hebrew University in Jerusalem (2003) and the Humboldt University of Berlin (2011-2012). Author of a dozen or so books, including Znaczenia modernizmu and Awangarda w cieniu Jatty (2005; English ed. 2009, received the Jan Długosz Award and the Prime Minister's Award). His most recent books include Agorafilia (2010; English ed. 2012) and Muzeum krytyczne (2011). Winner of the lgor Zabel Award for Culture and Theory (Barcelona, 2010). 
ideas are shared by many other authors, for example the concept that the global art history studies should reject the West-centred domination of the formal analysis and focus more on the "material" one. What is worth underlining, Zijlmans ends her concise text with a question whether this is going to work ${ }^{3}$, even though two years later, in the article included in the anthology co-edited by her, she seemed to have no doubts that this was going to work. She makes an assumption that art and art history/art criticism are a part of an "art system" which, being a "function" of a given social formation, is characterised by "self-observation" and "self-description". Precisely in this matter, the discourse produced by art history plays the role of a regulator and creator of the above-mentioned system. The current trend to accept peripheral creation as a subject of art criticism and art history is a symptom of the art system's globalisation. However, Zijlmans does not specify how (!) this is done but declares that this (!) is what happens, and she considers it a starting point for global art history ${ }^{4}$. The question asked earlier seems even more fundamental to the project which is called here "global art history".

Undoubtedly, what we currently observe is not only globalisation in terms of the economy and politics, the Empire of some kind, but also something we could call global art - outstretched between the world market, the financial superpower of corporations and art collectors on the one hand, and creation working for the Counter-Empire ${ }^{5}$ called the "Multitude" (with the unfortunate Polish translation as "rzesza") by Michael Hardt and Antonio Negri. In the end, Jeff Koons' global art is of a different nature than Artur Żmijewski's artistic output. It is also natural that - as it often happened in history - it is contemporary art which provokes historical questions and thus shapes art history. Although there is a debate on the chronology ${ }^{6}$ and condition of

3 Zijlmans, An Intercultural Perspective, 298.

4 Kitty Zijlmans, The Discourse on Contemporary Art and the Globalization in World Art Studies: Exploring Concepts and Approaches, ed. Kitty Zijlmans, Wilfried van Damme (Amsterdam: Valiz, 2008), 135-150. Speaking of the artistic system, the author refers to the following publications: Niklas Luhmann, Soziale Systeme: Grundriss einer allgemeinen Theorie (Frankfurt am Main: Suhrkamp, 1984); Nikla Luhmann, Die Kunst der Gesellschaft (Frankurt am Main: Suhrkamp, 1995).

5 Michael Hardt, Antonio Negri, Empire (Cambridge: Harvard University Press, 2001). On the translation of the word "Multitude" which is also the title of one part of Hardt and Negri's trilogy (Imperium, Multitude [the book has not been published in Polish yet], Rzecz-pospolita), cf. Praktyka Teoretyczna [anonymous team], Introduction in Michael Hardt, Antonio Negri Rzeczpospolita, trans. Praktyka Teoretyczna (Kraków: Ha!art, 2012), 48.

6 Generally speaking, some researchers signal earlier history of globalisation, at least going back to the capitalistic boom in the early modern period: Peter Sloterdijk, In the World Interior of Capital: Towards a Philosophical Theory of Globalization, trans. W. Hoban, (Cambridge: Polity Press 2013), Immanuel Wallerstein, World-Systems Analysis: An Introduction (Duke Univer- 
globalisation, or even the global character of culture, and every year there are more publications discussing global art and its history as well as attempts to build global art history as a scientific discipline, I still have an impression that Kitty Zijlmans' question quoted at the beginning of this article remains valid. Even James Elkins, who is considered to be an expert in this field, does not give a satisfactory answer to the question about what global art history should look like. His argument is reduced to a postulate that we should neutralise Western instruments and refer to local texts which may provide both knowledge and tools of research? ${ }^{7}$. Nonetheless, some scholars criticise him for applying them as stable matrices rather than treating them as real, often heterogeneous, historical sources, additionally enveloped with often equivocal interpretations ${ }^{\mathbf{8}}$. If we wish to draw any specific conclusions, they will rather be negative - we know what global art history should not be.

Hans Belting gives a fairly convincing answer to this question, suggesting that global art history should not be associated with the World Art Studies which focus more on studying universally understood world artistic heritage rather than the historical and geographical meaning of artistic creation. It is also neither history of global art, being quite a new phenomenon, nor an "extension" of today's Western art history to areas which have been neglected and ignored so far, namely the so-called Global South (formerly referred to as the Third World), and being a part of contemporary, global art culture because this would mean the continuation of the hegemonic strategy of universalistic, modernistic, Western art history. Belting has no doubts that global art, different from modern and until, recently, contemporary, so-called postmodernist art in terms of quality, is a challenge to art history and, to a certain extent, confirms his earlier theses concerning the breach of a discipline paradigm

sity Press, 2005). In our field of research, they are joined by Thomas DaCosta Kaufmann who disputes with Fredric Jameson, Art and Globalization, ed. James Elkins et al. (Pennsylvania: The Pennsylvania State University Press, 2010): Thomas DaCosta Kaufmann's views on pages: 13, 37-39; Frederic Jameson's views on pages: 13-15. Cf. also Thomas DaCosta Kaufmann, Toward a Geography of Art (Chicago: The University of Chicago Press, 2004).

7 James Elkins, Writing about Modernist Painting Outside Western Europe and North America in Compression vs. Expression. Containing and Explaining the World's Art, ed. John Onians (Williamstown MA, Sterling and Francine Clark Art Institute, 2006), 188-412; Is Art History Global?, ed. James Elkins (New York-London: Routledge, 2007); James Elkins, Why Art History is Global in Globalization and Contemporary Art, ed. Jonathan Harris (Chichester, Wiley-Blackwell, 2011), 375-386.

8 Monica Juneja, Global Art History and the "Burden of Representation" in Global Studies. Mapping Contemporary Art and Culture, ed. Hans Belting et al. (Ostfildern: Hatje Canz Verlag, 2011), 279-280. 
formulated aptly as "the end of art history"9. Obviously, he did not have in mind the end of reflection about art but transcending the frames of the paradigm - too narrow to embrace many traditional and contemporary art works. What is more, according to Belting, not only the academic discipline requires reconstruction but also the museum which, faced with global challenges (nota bene being realised mostly on the local level), cannot continuously follow previous models: neither MoMA, nor MoCA. The first one was entangled in the mythology of universalism ${ }^{10}$, the second - in the logic of late capitalism ${ }^{11}$. The new model should go against both the first and the second one as well as it should remove the disciplinary and institutional barriers separating e.g. an ethnographic museum from the one dedicated to art history, according to the movement springing in culture itself. Above all, it should provide a forum of public debate ${ }^{12}$.

\section{Global Art History and Post-Colonial Studies}

Regardless of the lack of a conceptualised system of "how to deal with global art history?", hence the lack of a cohesive theory, or even a proposition as such $^{13}$, analytical practice reveals an enormous field of research and extensive literature on this subject ${ }^{14}$. Its source can be mainly found in the area of the

9 Hans Belting, Das Ende der Kunstgeschichte. Eine Revision nach Jahren (München: Verlag C.H. Beck, 1994).

Cf., among others, Carol Duncan, Civilising Rituals. Inside Public Art Museums (London: Routledge, 1995), 102-132.

11 Rosalind Krauss, "The Cultural Logic of the Late Capitalist Museum", October 54 (Fall, 1990): 3-17.

These arguments appear in the published texts of the author and his collaborators in his project "GAM - Global Art Museum" in ZKM|Karlsruhe: Contemporary Art and the Museum. A Global Perspective, ed. Peter Weibel, Andrea Buddensieg (Ostfildern: Hatje Cantz Verlag, 2007), The Global Art World. Audiences, Markets, and Museums, ed. Hans Belting, Andrea Buddensieg (Ostfildern: Hatje Cantz Verlag, 2009), Global Studies. Mapping Contemporary Art and Culture, ed. Hans Belting et al. (Ostfildern: Hatje Cantz Verlag, 20011).

13 For some time, David Summers' monumental work was considered such a proposition - in his book, the author shifts the analysis from the visual to the spatial area which results in a polemic with fundamental Western categories of an analysis of a work of art. Cf. David Summers, Real Spaces. World Art History and the Rise of Western Modernism (New York: Phaidom, 2003). Cf. also David Summers, World Art History and the Rise of Western Modernism, or Goodbye to the Visual Arts in Compression vs. Expression. Containing and Explaining the World's Art, 215-234.

14 Apart from the publications mentioned in the previous footnotes, I would pay attention to synthetic studies and anthologies of texts (excluding monographs of specific regions):

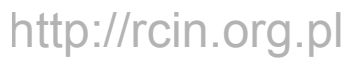


post-colonial studies which started to develop relatively late in our discipline, i.e. in the late 1980 s. The year 1989, when three important exhibitions related with the subject simultaneously took place, seems particularly important and, for certain reasons, symptomatic as it coincided with the collapse of Communism in Eastern Europe. In 1989 the following exhibitions were organised: Magiciens de la Terre in Centre Pompidou (curator: Jean Hubert-Martin), The Other Stories. Afro-Asian Artists in Post-War Britain in Hayward Gallery in London (curator: Rasheed Araeen) and the most interesting of all editions, the third edition of the Havana Biennale (curator: Gerardo Mosquera).

The basic argument of the art-historical post-colonial studies is the multitude of modernities and modernisms, the variety of meanings and realisations as well as their transcultural, dynamic and participatory (but not disconnected from the centre) character. In fact, most scholars admit it - also these who do not identify themselves with the post-colonial perspective, such as one of the best researches of Asian art - John Clark ${ }^{\mathbf{1 5}}$, or those who engage in the criticism of these studies somehow from the inside, such as an editor of the key magazine in the field - "Third Text" - Rasheed Araeen who accuse post-colonial theories (and even more the idea of multiculturalism) of masking the Western hegemony and preserving neo-colonial divisions ${ }^{\mathbf{1 6}}$. However, I would like to mention here an article, written by a well-known expert in Indian art, Partha Mitter, published in the December 2008 issue of "The Art Bulletin"17. The author begins his text with a critical analysis of colonial art history, asserting one-way import of so-called primitive art from

Globalization and Contemporary Art, ed. Jonathan Harris (Chichester: Wiley-Blackwell, 2011), Global Art, ed. Silvia von Bennigsen et al. (Ostfildern: Hatje Canz Verlag, 2009), Charlotte Bydler, The Global ArtWorld Inc. On the Globalization of Contemporary Art (Uppsala: Uppsala University, 2004), Julian Stallabrass, Art Incorporated. The Story of Contemporary Art (Oxford: Oxford University Press, 2004), Modern art in Africa, Asia, and Latin America. An Introduction to Global Modernisms, ed. Elaine O'Brien et al. (Chichester: Wiley-Blackwell, 2013).

John Clark, Modern Asian Art (Honolulu: The University of Hawaii Press, 1998). Cf. also John Clark, Modernities in Art: How are they 'Order'? in World Art Studies: Exploring Concepts and Approaches, 401-418.

16 Rasheed Araeen, "Our Bauhaus Other' Mudhouse", Third Text 6 (Spring, 1988): 3-14. Rasheed Araeen, A New Beginning. Beyond Post-colonial Cultural Theory and Identity Politics in The 'Third Text' Reader on Art, Culture and Theory, ed. Rasheed Araeen et al. (London: Continuum, 2002), 333-345; Rasheed Araeen, Art and Post-colonial Society in Globalization and Contemporary Art, 365-374.

17 Partha Mitter, "Intervention. Decentering Modernism: Art History and Avant-Garde Art from the Periphery", The Art Bulletin 4 (vol. XC, 2008): 543-544. Cf. also Partha Mitter, Reflections on Modern Art and National Identity in Colonial India: an Interview in Cosmopolitan Modernisms, ed. Kobena Mercer (Cambridge MA: The MIT Press, 2005), 24-49.

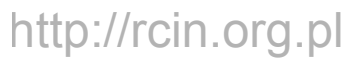


the colony to the metropolis and the movement which another scholar in another place calls mercantilism ${ }^{\mathbf{1 8}}$. This import was of course related with the Western hegemony and with the conviction that modernism, despite being inspired by the East, may solely emerge in the West and from there it can be exported to the East as a Western product. The East - according to experts in colonialism - is not able to generate contemporary art by itself. Moreover, by importing modernism, an Eastern artist fell into a trap of being between exact and inept imitation. In the first case, he/she was accused by the coloniser of "aping", in the second one - of the lack of progress in his scholarship. In other words, the colonial vision of contemporary art accepts only one modernism - the Western one - which of course conveys a universalistic, hierarchically implemented message. Mitter shows, however, that such a vision conceals an ideology rather than a true image of the relations between the metropolis and the colony. In essence, neither was "reception" of modernism passive in the colonies, nor was the movement unidirectional. In the first aspect, Mitter points to the example of the 19th-century India to show the spreading of academic painting as a synonym of Western colonisation. What is meaningful from the point of view of colonial politics, the academic art touched upon Oriental subjects known to Western art. This tendency was contradicted by nationalist concepts of returning to historical sources and exploitation of art based on traditional, Indian patterns. Nevertheless, the avant-garde movement of the early 1920 - above all cubism which was very popular in the region - overthrew this order. From that moment on, cubisminspired Indian art began to function as a critique of colonial academism, but also nationalism expressed in art modelled on the Indian tradition. In the second aspect, as emphasised by the author, Western references to the so-called primitivism were not solely formalistic inspiration. In his opinion, by pointing to the "other" art, Western artists undermined this cultural hegemony; by rejecting classical and realistic foundations of Western art and by constructing rebellious poetics and messages, they challenged art tradition and imperial politics of the West as well as capitalist and bourgeois attitudes which were the foundation of Western societies including the colonial ones ${ }^{19}$. Mitter concludes that New Art History, based on post-colonial premises, may disclose a different side of modernism: pluralist, open and decentralised, and present a complex relation between locality and globalism, but also mutual

18 Ming Tiampo, Cultural Mercantilism. Modernism's Means of Production: the Gutai Group as Case Study in Globalization and Contemporary Art, 212-224.

19 Similar opinions were sometimes expressed by Western researchers not related with postcolonialism. Cf. Patricia Dee Leighten, Re-Ordering the Universe: Picasso and Anarchism, 1897-1914 (Princeton NJ: Princeton University Press, 1989). 
inspirations between peripheries and centres in their dynamic shape. This obviously means - and is underlined by nearly all scholars in the field - that the post-colonial condition not only concerns former colonies but also, or actually most of all, (former?) metropoleis.

In this context, Partha Mitter introduces very interesting notions: "cosmopolitan primitivism" and "virtual cosmopolitism" also called "imagined primitivism", which is clearly a cunning reference to Benedict Anderson's nationalist theory based on the notion of "imagined community". These notions imply that referring to the so-called primitive was very common among modernist artists in the early 2oth century and united them ideologically and artistically in their critical strategies towards aesthetic, capitalist and colonial politics of the West, regardless of the country and continent of their origin. ${ }^{\mathbf{2 0}}$ It is worth adding here that just as avant-garde artists in the West reached for "primitive" works from distant sources, Indian artists drew from their own sources - this situates these two artistic groups in two distinct positions and loosens the bonds within this international primitivist coalition. There is yet another discrepancy between them: Western artists focused on the critique of their "own" colonialism, at least of their own countries, whilst "other" artists, Indian artists in this case, fought with foreign colonialism. Nevertheless, taking up these issues surely made these "communities" be diversely located in the world map back then. It is, however, important to the author that it was the avant-garde, inspired by local folk ("primitive") art, which made it possible for Indian artists to liberate from two traps of colonialism: Western imperial and effectively Oriental - academism and nationalism manifested in Indian aristocratic traditional art (e.g. flat, decorative miniatures).

\section{Post-Colonial Studies and (Eastern) Europe}

Post-colonial studies are one of the basic impulses to think about art globally. Should we develop this kind of reflection with regard to Eastern European art in this decentralised, pluralist perspective, we must definitely get through with the post-colonial studies.

We should notice, however, that various publications devoted to global art, and more precisely, to art history seen from the global perspective, de facto omit Eastern Europe. It is sometimes alluded to but in very general terms. Most materials are related with studies on Asian, African, Latin-American and Australian art culture, usually treated separately, somehow next to each

20 More extended argumentation of this kind is presented by the author in Partha Mitter, The Triumph of Modernism. India's Artists and the Avant-Garde, 1922-1947 (London: Reaktion Books, 2007). 
other, instead of being evaluated in the context of their interactions. To such researchers, Eastern Europe is neither a problem for analysis nor interesting research material. The artistic reflection presented here is not to be found in their synthetic interpretations. Charlotte Bydler, trying to sketch a global panorama of the discipline cultivated outside the West, writes about art history in Africa, Turkey, Scandinavia, Korea, but she does not refer to Eastern Europe $^{21}$. In a way, it is actually our fault. Despite several attempts to master art historiography of the region, predominantly made in Germany by Adam Labuda and his students ${ }^{\mathbf{2 2}}$, a synthetic work about the development of art history in Eastern Europe, which would collect and compare experiences of theoreticians and researchers from different countries, has not been written yet. Certainly, it is not easy as these countries are quite numerous and their inhabitants speak and write using various, little-known languages. Nevertheless, such work must be performed by someone one day. On the other hand, as Jan Bakoš notices, global art history is to a small extent the subject of EasternEuropean art historians' interest ${ }^{23}$, which is not entirely true but the fact is that there have been no serious studies in this field published in our part of Europe. As a result, we do not participate in this debate on the international level. In other disciplines such as literary studies or political and economic history, the situation is a bit different as proved by Jan Sowa's recent daring re-writing of the Polish history ${ }^{\mathbf{2 4}}$ and earlier, Ewa Thompson's studies on Russian literature - read from the colonial point of view ${ }^{25}$. However, this does not mean that such perspective is received uncritically in the field of research on history and literature ${ }^{26}$. Thus, drawing inspiration from the post-colonial studies in Eastern-European art history, being quite a different phenomenon from literature or history of politics and economy, is not that simple. In order to face this phenomenon at all, we must first rigorously scrutinise art-historical instruments of the post-colonial studies, if we want to go deeper instead

21 Charlotte Bydler, The Global ArtWorld Inc., 159-179.

22 Cf. e.g. Die Kunsthistoriographien in Ostmitteleuropa and der nationale Diskurs, ed. Robert Born, Alena Janatková, Adam S. Labuda (Berlin: Gebrüder Man Verlag [Humboldt-Schriften zur Kunst- und Bildgeschichte], 2004).

23 Jan Bakoš, in Art and Globalization, 206.

24 Jan Sowa, Fantomowe ciało króla (Kraków: Universitas, 2011).

25 Ewa Thompson, Trubadurzy Imperium. Literatura rosyjska i kolonializm (Kraków: Universitas, 2000).

26 Cf. D. Skórczewski, „Wobec eurocentryzmu, dekolonizacji i postmodernizmu. O niektórych problemach teorii postkolonialnej i jej polskich perspektywach", Teksty Drugie 1-2 (2008): 33-35. 
of merely utilising slogans concerning multitude, decentralisation, critique of hegemony, hybridity of the subject, etc.

I believe that the key matter is criticism of Eurocentrism, intensively exploited by post-colonialists. It is one of our main problems as well. Without dissection of this notion, it is even hard to think about employing this perspective in research devoted to Eastern-European art. The path from this point to globalism, or global history of Eastern-European art, leads through Europe and not in opposition to it. Incidentally, not only European peripheries encounter this issue. Many researchers and observers of global culture agree that farther, intercontinental peripheries also need to take Europe into consideration rather than reject its presence. Because the alternative, as Gerardo Mosquero wrote, is not the "Marco Polo syndrome", and not the return to cultural isolationism or pre-colonial "purity" but discovering the syncretism of modern and contemporary culture, the symbiosis of European and local influences ${ }^{\mathbf{2 7}}$.

To post-colonial researchers, Europe is a negative figure largely homogenising the culture of the Old Continent. Frankly speaking, they can afford such simplification because, for their own purposes, debating over intra-European colonisation is meaningless. They associate Europe with historical experience of European colonialism represented by Great Britain, France, Belgium, Netherlands, Spain and Portugal. They are not concerned with such countries as Moldavia, Lithuania, Slovakia or Slovenia (often mistaken with each other), Poland - having its own episode of Eastern colonisation, Russia or even Germany, although it was in Berlin where Otto von Bismarck's initiative resulted in organising a conference about the colonial division of the world in the years 1884-1885. Obviously, Germany had overseas colonial ambitions; it even had colonies. Eventually, similarly to Austria and Russia, it concentrated on conquering neighbouring territories rather than exploiting remote continents (earlier Poland acted similarly). Italy's colonial adventure was slightly grotesque; Scandinavians, on the other hand, did not have such experiences at all, not mentioning the Irish - perhaps even more painfully affected by the British imperialism than Indians - who did not enjoy the status of the "pearl in the crown". The completely inverted colonial scheme is manifested by Greece, the home of European civilisation colonised by the non-European superpower. Clearly, there is no one Europe: there is colonial and colonised Europe, imperial and invaded Europe, dominant and subordinated Europe. Comments regarding European pluralism and criticism of the continent's homogenising vision are crucial to us because from our perspective, the notion

27 Gerardo Mosquera, The Marco Polo Syndrome. Some Problems around Art and Eurocentrism (1992) in The Biennale Reader, ed. E. Filipovic et al. (Ostfildern: Hatje Canz Verlag, 2010), 416-425. 
of Eurocentrism is doubtful, while its post-colonial criticism definitely too simplified.

This has fairly serious consequences: an impossibility to maintain another key post-colonial notion, namely the notion of the "other". To the British coloniser, the Indian is evidently the "other", just like the Arab to the French or the American Indian to the Spanish. Czechs or Hungarians are not really the "other"; they are rather the "close other", "not-quite-other" ${ }^{28}$, etc. This also works the other way around but not in the case of subjective colonial relations. Moreover, the Polish will also consider the Indian and the African as the "other", especially in the context of culture. The "close other", on the other hand, functions within the same episteme, in the same system of perceiving the world, in the area of the same cultural, traditional, religious models, etc. Consequently, the culture of the European coloniser or occupant is not totally strange, or at least it is not as strange as in transoceanic relations. This makes a fundamental discrepancy as it also defines artistic relations. To artists from Prague or Zagreb, Western-European art centres were not so much external as they were to e.g. Shanghai art circles, most modernist and lively ones in the Chinese culture of the 1930s. Hence, drawing from Parisian models (e.g. cubism) bore a different meaning in Lviv than in Calcutta. It also reached a different ground. Marginal European states, not only these on the East of the continent but also the Northern ones (an often forgotten fact), are not the countries where "art history has no history", as Andrea Buddensieg wrote about Rasheed Araeen ${ }^{29}$. Therefore, the allegedly analogical and syncretic (as we have called it so far) reception of cubism in Cracow or Riga is not same thing as reception of cubism in Calcutta.

And finally the third question: who is the coloniser and who is colonised here? In attempt to respond to it, or in fact to expose difficulties in giving the response, I will only focus on the period after 1945. From that moment, Eastern Europe is - to a variable extent and with a different dynamic - occupied by the USSR. Cultural colonisation of Eastern-European countries expressed in socialist realism takes place in the late 1940s. By then, everything seems to be in the right place: there is the coloniser (USSR) and there are the colonised (Poland, Czechoslovakia, Hungary, etc.). In the mid 1950 s the situation begins to be complicated. Generally speaking, the coloniser withdraws or is

28 In art-historical literature known to me, this notion is used by Bojana Pejić, The Dialectics of Normality in After the Wall. Art and Culture in Post-Communist Europe, ed. Bojana Pejić, David Elliott (Stockholm: Moderna Museet, 1999), 020. She also refers to Boris Groys' notion of fremde Nahe but she does not provide the source.

29 Andrea Buddensieg, Visibility in the Art World: the Voice of Rasheed Araeen in Contemporary Art and the Museum, 52. 
withdrawn from the cultural colonisation - again in various degrees and with different dynamics, depending on a country. At least this is what happens in Poland. What is, therefore, the decolonising strategy of Poland and other Eastern countries? It is patterned on Western states, mainly France, where - for many reasons - opportunities for emancipation can be found. For example, in French informel painting, at least as per conviction of local cultural leaders of the Khrushchev Thaw. Since it is not "indigenous" abstract art, the question arises whether this might be French cultural colonisation. If so, one wave of colonisation would be ousted by another, only that the second one was warmly welcomed by the colonised. To some extent, it would resemble the position of cubism in India, which, as already mentioned, forced out par excellence the art of the colonisers, i.e. academism. However, this is not a very close analogy because cubism, "imported" from Paris to Calcutta around 1922, not only had origins in the same geographical region as academism, but also, or most of all, was critical towards this region. Calcutta, therefore, was the destination of art which revolted against art associated with the colonisers, although it was coming from the very colonisers' country. In the mid 1950 s in Poland, the situation is slightly different. The geographical and, of course, political vector of colonisation changes its direction. What complicates it even more is that Paris and the afterwar French culture itself becomes a subject of American cultural colonisation, as discussed by Serge Guilbaut ${ }^{\mathbf{3 0}}$. The Marshall Plan, therefore, made the French drive back. What came next was, for example, colonisation of French cinematography, at least until the emergence of the "new wave" which - what is worth remembering - was a reaction to Hollywood movies. Its political character was manifested not only in topics it touched upon but also in methods of shooting films - constituting the critique of commercial, that is American, cinematography.

However, if we ignored the specificity of Paris and looked at the situation of Eastern-European art culture of the cold war period in the categories of global cultural strategies employed by the antagonistic parties and their artistic manifestations, other complications come to light. Obviously, the cold war was global and its key protagonists, the USSR and the West (the US in fact), went into competition in terms of their cultural strategies on the territories of the Third World countries as they were called back then. In the artistic sense, it was the competition between two myths of universalism, or at least two stylistics with universal ambitions: modernism and socialist realism. The example of the Khrushchev Thaw shows that the question about the coloniser becomes more complex and that the cultural war between the

30 Serge Guilbaut, Jak Nowy Jork ukradł ideę sztuki nowoczesnej. Ekspresjonizm abstrakcyjny, wolność i zimna wojna, trans. Ewa Mikina (Warszawa: Hotel Sztuki, 1992). 
East and the West rages on not only in the Third World but also in the Second and even the First World which is an entirely separate issue. In other words, there might be two colonisers here - one is described as the oppressor, the other as the liberator.

The fourth matter is more of general nature. Post-colonial research is mainly developed in the field of literary studies or philosophy which in fact is also a type of literature. These two fields are the source of key notions and methods of analysis which not always commensurate with art-historical research. The polemic with this perspective was once presented by one of the most interesting researchers of visual culture in the context of the post-colonial condition - the post-colonial condition does not need to correspond with the post-colonial theory with which he nota bene argued - namely, Rasheed Araeen, chief editor of the major specialist periodical "Third Text". In the conclusion of the extensive selection of texts published in this magazine, given a meaningful title A New Beginning, the author depicts main dilemmas concerning the system of notions and the ideology of the post-colonial studies; paradoxically, dilemmas generated within the perspective of the post-colonial condition which, in his opinion, characterise not only the former colonies' territories but above all - the metropoleis ${ }^{31}$. It is worth noticing that the postcolonial theory should not be identified with the post-colonial condition. The latter is broader and can be the subject of research conducted from many different perspectives.

Let us start with the basic concern: literature uses the language which by nature, if one could say so, is national or ethnic which, essentially, is not the same thing. For obvious reasons, a writer in exile, using a foreign language to write, creates space between his own language and the acquired one, the one imposed by circumstances. The contemporaneity of literature is always mediated by the language - whether it is the language of the colonised (the local language) or the colonisers (the language of the diaspora). Participation in contemporary culture, thus, does not mean "direct" participation in the universal community of contemporary articulation of thoughts. Metaphors, notions, constructs, literary narratives, etc., are somehow translated to a specific language that already has its own "burden". In visual arts, especially in the so-called high art, we have similar traditions which "burden" modernity or modernism (which is of course not the same thing) but participation in this art culture is linked with the myth of the "international style" - allegedly universal and read in a more direct way than nationally burdened literature. We have been convinced that people see more universally than they read.

31 Rasheed Araeen, A New Beginning. Beyond Post-colonial Theory and Identity Politics in The 'Third Text'Reader, 333-345. 
These beliefs are confirmed, as it seems, by the most recent research on neuroarthistory currently developed by one of the most interesting promoters of the World Art Studies, John Onians ${ }^{32}$. But Araeen follows another trail. Being engaged in a polemic with Homi Bhabha (a literary studies theoretician) and his key notion of the "hybrid subject" and the "culture in-between", and denouncing these notions for buffering tension between the colonised and the coloniser, he notices that artists in exile such as Brancusi (Romanian) or Picasso (Spanish) as well as many other less known figures coming from other continents neither perceived themselves as "expatriates" nor felt affiliation with the diaspora. On the contrary, they saw themselves as part of the same culture, part of modernity, no matter where they were coming from, they felt they created contemporary art, regardless of the country of their origin and their locality, although - let us add - art historians find such traces in their artistic output. They felt themselves a part of one culture, modern art. The author continues that their so-called exile was by no means imposed; it reflected their willingness to be in the centre (in Paris) and co-create contemporary art. Summarising this fragment of his argument, he ironically observes that the post-colonial theory cannot and does not want to understand it $^{33}$.

To us, art historians, these comments are crucial. Independently of the radical approach presented by the editor of "Third Text", they attract attention not only to distinctiveness of the artistic experience as compared with other creative experiences and development of a more suitable theory to describe it but they also - somehow incidentally, in the context of mentions concerning Brancusi and Picasso (and we could enlist here several leading contemporary artists living in Paris at that time) - acknowledge a certain European modernist community or a sense of community, regardless of the country of origin of a given artist. To researchers of Eastern-European art, thus, the presented critical reflection over the post-colonial theory could be of the utmost importance.

This long argument is not aimed at discouraging readers from the postcolonial studies and making them put them aside as useless in analysing the global dimension of Eastern-European art. It is quite the opposite in some sense: in my view, many words in the post-colonial glossary may turn out to be useful under the condition their criticism is taken into account. I would

32 John Onians, A Brief Natural History of Art in Compression vs. Expression. Containing and Explaining the World's Art, ed. John Onians (Williamstown MA: Sterling and Francine Clark Art Institute, 2006), pp. 235-249; John Onians, Neuroarthistory: Making More Sense of Art in World Art Studies: Exploring Concepts and Approaches, 265-286; John Onians, Neuroarthistory. From Aristotle and Pliny to Baxandal and Zeki (New Haven CT: Yale University Press, 2008). 
say that we need European criticism of the post-colonial studies, somewhat in their own spirit, i.e. we need pluralism and decentralisation, rejection of hegemony and homogenisation; we need specific art-historical critical European studies not as an alternative to the post-colonial studies but as their filter. To put it concisely: the post-colonial studies are shaped against Europe globalisation of Eastern-European art history has to happen through Europe.

\section{Global Comparative Studies}

I wrote a programmatic article about horizontal art history once ${ }^{34}$. As it usually happens with programmes, this concept is also far from being perfect but - and that is not exceptional either - I am attached to it as its author. I would like to bring it in to the discussion about global art history. I will also add that it is founded on comparative art history as my assumption is that we get to know things by comparing them and I am not the only one to think that. However, the point is not about looking for mutual influences as this is the subject of a different reflection but about comparing seemingly remote areas of art culture in order to ferret out their diversity and eventually, exhibit global polyphony of art in - I shall repeat - the horizontal, parallel dimension instead of being focused concentrically around (Western) art centres. This method would involve two moves: firstly, horizontal historical cuts of the selected moments in global history and art history and, secondly, comparisons drawn in this perspective. It could be done in various areas - on the transnational, transregional and finally, global level.

I also spoke of three such historical cuts of the post-war culture when politics or history specifically intertwined with art.

First of all, I spoke of the end of the 1940 s when the cold war intensifies and there is mobilisation on both sides of the barricade which significantly affects art in the global scale. This is when the global cultural cold war actually begins, followed by the elimination of (often illusory) remains of artistic freedom in Eastern-European countries; in Czechoslovakia, Poland, Hungary - in all these countries communists gain total power in the years 1947-1948 which, in terms of art culture, leads to introducing socialist realism as an obligatory doctrine. On the other side of the Atlantic Ocean, the strategy of globalising modernism is crystallised as an expression of the "American lifestyle", often triggered by - which is a paradox only on the surface - conservatives or liberal conservatives some of whom hitherto declared to be strongly against modern art. The same art shifts from being radical to being liberal, which should be

34 Piotr Piotrowski, "O horyzontalnej historii sztuki", Artium Quaestiones XX (2009), 59-73. Earlier In English: "On the Spatial Turn, Or Horizontal Art History", Umeni/Art 5 (2008): 378-383. 
interpreted in the following way: it moves from leftist engagement, strong in the previous decade, to political non-involvement which of course makes it easier to use such art in the global cultural war by the US administration. This is the beginning of "stealing" Parisian contemporary art by New York ${ }^{35}$, the beginning of competition and at the same time the political globalisation of two myths of the universal culture: modernism and socialist realism, hence liberalism and socialism. What should be underlined, both Eastern and Western part of Europe becomes the arena of this conflict, but also the so-called Third World is subject to attempts of neo-colonisation by both the USSR and the USA. We should also remember that in 1949 China joins to communist world, while socialist realism becomes there the only acceptable, official artistic doctrine. So we have the same visual schemes as in Romania, Lithuania or Poland, only the eyes of characters on these images are more slanting. The late 1940 s also give start to liberation movements in these colonies. The symbolic act of regaining independence of India in 1947 (and its division into two countries) also significantly affects the shape of the country's cultural policy but also the movements of the so-called non-involved states, in Europe represented by Yugoslavia. It would shortly reject the doctrine of realistic socialist art, replacing it with "socialist modernism"; the first sign of such a shift would be formation of the Croatian EXAT 51 group.

Secondly, the period before and after 1968 is yet another turning point on the map of global culture. The political and artistic arena undergoes fundamental revaluation; the wars in the Near East and in Vietnam are a new symptom of the cold war; intensification of the Southern American regimes exerts much influence on the local art culture; intellectual, cultural (also artistic) and moral revolution in the West as well as the Prague Spring in the East has major consequences visible in transformations of the art world. Finally, it is the time of the cultural revolution in China which has an immediate impact on Western-European culture. In that year, India hosted the first graphic arts biennial which - although it was not the first ever biennial outside the Western world (the very first one was organised in 1951 in São Paolo) - confirmed the fact that the so-called Third World countries, or "non-involved countries", among which India played an important role, appeared on the global art scene. Entering the field of comparative studies on Eastern Europe and South America, nota bene developed by Klara Kemp-Welch from Great Britain and Cristina Freire from Brazil ${ }^{36}$, we should notice that, for instance, artists from Poland

35 Serge Guilbaut, Jak Nowy Jork ukradł ideę sztuki nowoczesnej.

36 Klara Kemp-Welch, Cristina Freire, "Artists' Networks in Latin America and eastern Europe (Special Section/Introduction)", Art Margins 2-3 (Vol. 1, 2012): 3-13. Dr Klara Kemp-Welch is also an author of the MA Programme in the Courtauld Institute of Art in London: Countercultures: 
and Argentina started their careers in the similar point of late modernism development, i.e. in the mid-1950s, which coincided with the liberalisation of artistic life in both countries - after banning Peronism in Argentina and Stalinist cultural policy in Poland (toutes proportions gardées). Both countries experienced the emergence of great energy, even euphoria over modernist art in both cases taking from French (not American) sources. In both countries, of course, the 1960 s are the years of the neo-avant-garde, including conceptual art, but in Argentina it is the time of remarkable political radicalisation leading to identification of art with direct political action, while in Poland it served as an escape from politics. Thus, the year 1968, which in both countries is very meaningful, looks completely different than $1955^{37}$.

Thirdly, the horizontal "cut" around 1989: the collapse of a few regimes in the world (Eastern Europe, Latin America, South Africa) and at the same time the aggravation of the political course in China, the emergence of the global art market, great exhibitions and the new axis of the world organisation: North-South, alternative to the cold-war East-West division. The year 1989 also started a debate about the "former West"38, "provincialisation of Europe"39 and movements of artistic and anthropological criteria of artistic analysis on the global scale; as claimed by Alexander Alberro, this is in fact a new era in the world art history ${ }^{40}$. The point is not only that everywhere in the world, including Eastern Europe, artists become interested in global issues (Artur Żmijewski in Poland, Pode Bal group in Czech Republic, Tamas Szentjóby [St. Auby] in Hungary) but also that the end of the Cold War somehow provokes comparisons of art cultures originating from harsh regimes (like in

Alternative Art in Eastern Europe and Latin America, 1953-1991. Accessed on July 20, 2015, http:// www.courtauld.ac.uk/degreeprogrammes/postgraduate/ma/specialistareas/countercultures.shtml.

37 I elaborated on this problem in a paper presented at the II International Congress of Polish History "Poland in Central Europe" in Cracow in October 2012 (section "Traces of the Avant-Garde - Art and Architecture in Central Europe after 1945" organised by Wojciech Bałus and Andrzej Szczerski): Piotr Piotrowski, Globalising Central-East European Art (typescript).

38 Cf. the project entitled Fromer West: BAK - basis vooor actuele kunst, Utrecht http://www. formerwest.org/.

39 Behind this metaphor, taken of course from the title of a well-known book by Dipesh Chakrabarty, Prowincjonalizacja Europy. Myśl postkolonialna i różnica historyczna, trans. Dorota Kołodziejczyk, Tomasz Dobrogoszcz, Ewa Domańska (Poznań: Wydawnistwo Poznańskie, 2011), I understand such an outlook on the world art culture which will reduce comprehension of the West and the Western art to the position of one of many provinces.

40 Alexander Alberro, Periodising Contemporary Art in Crossing Cultures. Conflict, Migration, and Convergence, ed. Jaynie Anderson (Melbourne: The Miegunyah Press, 2009), 935-939. 
Poland and South Africa). There is also the question of comparing changes which shaped contemporary art with the later world rebellion called the "Arab Spring" and art that defined it.

\section{Alter-Globalist Art History}

And the final question is: what does this kind of scientific perspective have to do with economic, political, civilisational and cultural processes of globalisation? Assuming that globalisation is the Empire's instrument ${ }^{41}$, let us ask how art history can be perceived in this context as a humanistic discipline? For this purpose, I would like to introduce yet another term: alter-globalism.

Again, to put it very briefly: alter-globalism is a movement of resistance to globalisation understood in the terms of economy and politics but also art and, more broadly speaking: culture. It originates from anti-globalism, i.e. the opposition to global exploitation of employees by big corporations. Anti-globalist activists soon realised, however, that should the critique and resistance to globalisation be effective, the opposition movement must have a global character as well. Otherwise, it will be easily pacified. As a consequence, the 2001 World Social Forum in Porto Alegre, Brazil, approved the global resistance perspective. From that moment on, the movement started to spread rapidly all over the world - also in Eastern Europe ${ }^{42}$. In our part of the continent, this movement may be seen in the context of the so-called post-Communist condition which is not at all local but universal ${ }^{43}$. To a certain extent, it seems obvious, since the cold war and so the Communist condition were of a global character, the more the post-Communist condition should be global as well. In other words, we are faced with the question about the global nature of the post-Communist studies. Nonetheless, this is a separate issue which requires individual elaboration which - until now - in art history has not been yet systematically undertaken.

41 As indicated above, I use this notion in the understanding of Hardt and Negri. The authors also introduce the term: anti-empire as an opposition to the globalisation processes: Michael Hardt and Antonio Negri, Empire.

42 Grzegorz Piotrowski, Alterglobalism in Postsocialism. A Study of Central and Eastern European Activists (Florence: European University Institute, Department of Political and Social Sciences, 2011), doctoral thesis.

43 Susan Buck-Morss, The Post-Soviet Condition in East Art Map. Contemporary Art and Eastern Europe, ed. IRWIN (London: Afterall Book, 2006), 494-499. Boris Groys, Art Power (Cambridge MA: The MIT Press, 2008), esp. chapters: "Beyond Diversity: Cultural Studies and Its Post-Communist Other", 149-163, "Privatization, or Artificial Paradises of Post-Communism", pp. 165-172. Boris Groys, Back from the Future in 2000+ Art East Collection. The Art of Eastern Europe, ed. Zdenka Badovinac, Peter Weibel (Wien-Bozen: Folio Verlag, 2001), 9-14.

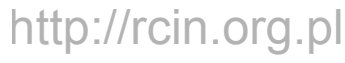


Art history is part of the humanities - the latter having of course many faces. Many of us interpret this discipline's functions our own way; understanding it has also changed over time. The definition of the humanities close to my outlook is that it is a part of the public debate, or more, it is an element of the strategy of resistance to the authorities and oppression, at the same time being on the side of emancipation and liberation. Art history which would handle such undertaking in the horizontal and comparative perspective (as discussed earlier in this article) - the global undertaking which would involve exposing repressive practices directed towards margins, peripheries both geographically and topographically (i.e. within certain localities) - I would call alter-globalist art history. It could concern both the past and the present, both curatorial and publishing practices, policies of both universities and museums, etc. Its key feature should be criticism and resistance to centralistic and exclusive art-historical activities and ability to reveal mechanisms of building hierarchy and hegemony as well as repression and denial in the global scale.

Research on conceptual art could be illustrative to this type of thinking. In my opinion, the milestone in the global development of such research in the alter-globalist version was the 1999 exhibition Global Conceptualism: Point of Origins organised in the Queens Museum of $\mathrm{Art}^{44}$. It is not the right place to discuss it in detail but we ought to notice that it was quite a natural reaction to another exhibition of conceptual art of an overtly hegemonic and Western-centric character, namely the one entitled L'art conceptuel. Une perspective ${ }^{45}$ organised in the Parisian Musée d'Art Moderne de la Ville de Paris ten years earlier. At the New York exhibition and in the research developing under its influence, Western conceptual art (mainly Anglo-American) was let us say - "provincialised", which means that it was exhibited as one of many or among many (South-American, Asian, Russian, Eastern-European, etc.) instead of being considered normative or paradigmatic. The West (England and the US) were reduced to one of the geo-historical territories where conceptualism was developing but it was deprived of the exemplary function. Whereas the remaining regions were presented against different traditions, with their own artistic dynamics and chronology. Therefore, if in (Western) modern art history textbooks conceptualism is analysed in the stream of art of Western provenance developing in the world, let us say: in the category

44 Global Conceptualism: Points of Origin, 1950-1980s, ed. Luis Camnitzer, Jane Farver, Rachel Weiss (New York: Queens Museum of Art, 1999).

45 L'art conceptuel. Une perspective, ed. Claude Gintz (Paris: Musée d'Art Moderne de la Ville de Paris, 1989). Cf. also the paradigmatic text from this catalogue reprinted in the influential quarterly October: Benjamin Heinz-Dieter Buchloh, "Conceptual Art, 1962-1969: From the Aesthetics of Administration to the Critique of Institutions", October 55 (Winter, 1990): 105-143. 
of global domination of the Anglo-American analytical art, here we had an image of the horizontal diachrony of various and equally important art-historical perspectives. It seems that the shift of the scientific paradigm towards alter-globalism was most beneficial to studies on Latin-American art, always developed with the conviction of this continent's separateness and independence of the West ${ }^{46}$. The development of studies on Eastern-European conceptual art should also be observed in this context as they show considerable independence and individuality of its progress comparing to Western models, at the same time noticing its political meaning understood as resistance to the Communist system ${ }^{\mathbf{4 7}}$.

Alter-globalist art history, therefore, is not a utopian programme; on the contrary, I would say, and the evidence is provided by the above-mentioned example of conceptual art studies. Perhaps its academic beginnings are not impressive, since this way of thinking is more visible in the work of curators who quite rapidly - considerably faster than academic institutions - took up the challenge of globalisation. Again, it is confirmed by the above example of

46 Cf. among others: Mari Carmen Ramírez, Tactics for Thriving on Adversity: Conceptualism in Latin America, 1960-1980 in Global Conceptualism: Points of Origins, 1950-1980, 53-71; Mari Carmen Ramírez, Blue Print Circuits: Conceptual Art and Politics in Latin America in Latin American Artists of the Twentieth Century, ed. A. Rasmussen (New York: MoMA, 1993); Cristina Freire, Arte Conceitual (Sao Paolo: Jorge Zahar, 2006); Luis Camnitzer, Conceptualism in Latin America: Dialectics of Liberation (Austin: University of Texas Press, 2007); Andrea Giunta, Avant-Garde, Internationalism, and Politics (Durham: Duke University Press, 2007). A significant anthology of the Southern-American art criticism, entering intoa polemic with the Western view of the art on the continent is Beyond the Fantastic. Contemporary Art Criticism from Latin America, ed. Gerardo Mosquera (Cambridge MA: The MIT Press, 1996). The title of the volume was drawn from the typical, Oriental exhibition of the art of the continent: Art of the Fantastic. Latin America, 1920-1987 (Indianapolis Museum of Art, 1987). Cf. also Mari Carmen Ramírez, Brokering Identities: Art Curators and the Politics of Cultural Representation in Thinking about Exhibitions, ed. Reesa Greenberg, Bruce W. Ferguson, Sandy Nairine (London: Routledge, 1996), 21-38.

47 Cf. among others: Laszlo Beke, Conceptual Tendencies in Eastern European Art in Global Conceptualism: Points of Origins, 1950-1980s, pp. 42-51; Piotr Piotrowski, Awangarda w cieniu Jałty. Sztuka w Europie Środkowo-Wschodniej w latach 1945-1989 (Poznań: Rebis, 2005), pp. 341-367; Die Totale Aufklärung. Moskauer Konzeptkunst, 1960-1990/ Total Enlightenment. Conceptual Art in Moscow, 1960-1990, ed. Boris Groys et. al, (Frankfurt-Ostfildern: Kunsthalle/Hatje Canz Verlag, 2008); Victor Tupitsyn, The Museological Unconscious (Cambridge MA: The MIT Press, 2009), pp. 101-121. Boris Groys, History Becomes Form. Moscow Conceptualism (Cambridge MA: The MIT Press, 2010). Cf. also the most recent debate on the subject: Conceptual Art and Central Europe (Zdenka Badovinac, Eda Čufer, Cristina Freire, Boris Groys, Charles Harrison, Vít Havránek, Piotr Piotrowski, Branka Stipančić), Part I and Part II "e-flux", Journal 40 (12/ 2012) and Journal 41, (1/2012):

http://www.e-flux.com/journal/conceptual-art-and-eastern-europe-part-i/ http://www.e-flux.com/journal/conceptual-art-and-eastern-europe-part-ii/ 
studies devoted to conceptual art. Some exhibitions and curatorial projects of course complied with globalisation, others chose a critical approach, for instance some of the (increasing in numbers) biennials -- and selected global exhibitions. There are art critics who even expect these events to provide space for shaping a global politeia, i.e. creating the world constitution which could protect the world from being exploited by the Empire. Boris Groys writes about this issue in reference to the Istanbul Biennial ${ }^{48}$ and Charles Esche elaborates on it in the context of the Havana Biennial - its third edition, to be precise (unfortunately, the subsequent ones have not satisfied these hopes) ${ }^{49}$. It is also analysed by Okwui Enwezor, the artistic director of one of the most interesting editions of the Documenta exhibition: Documenta 11, proving that great world exhibitions may (but of course do not have to) be counter-hegemonic or counter-normative to the Western system ${ }^{50}$. While Ranjit Hoskote, pointing to the example of the seventh Gwangju Biennial in Korea, uses the term "biennial of resistance" to define low-budget events of a distinctly rebellious character ${ }^{51}$. Also Thomas Fillitz notices the possibility of building "zones of contact" between different cultures (the very expression comes from the title of the 2006 Biennial in Sydney entitled Zones of Contact) on the basis of the Dakar Biennale (Dak'Art). In his view, biennials can generate some kind of parallelism of perceiving different cultures and create an alternative to museums which are still - despite slogans they promote - subject to the domination of the Western paradigm of understanding art ${ }^{52}$.

The necessity of building the world politeia stems from the conviction that the lack of control over the global capital will cause the democracy crisis. So far, the democratic system has functioned within the national state within which, until recently, the economy has functioned as well - at least key economic decisions were taken in this area, subsequently negotiated with other national states. However, the economy escaped the control democratically

48 Boris Groys, "From Medium to Message. The Art Exhibition as Model of a New World Order", Open. Cahier on Art and the Public Domain (The Art Biennial as a Global Phenomenon) 16 (2009), 56-65.

49 Charles Esche, Making Art Global: A Good Place or a No Place? in Making Art Global (Part 1). The Third Havana Biennial, 1989, ed. Rachel Weiss (London: Afterall, 2011), 8-13.

50 Okwui Enwezor, Mega-Exhibitions and the Antinomies of a Transnational Global Form in The Biennale Reader, ed. E. Filipovic et al. (Ostfildern: Hatje Canz Verlag, 2010), 426-445.

51 Ranjit Hoskote, Biennials of Resistance: Reflections on the Seventh Gwangju Biennial in The Biennale Reader, 306-321.

52 Thomas Fillitz, Contemporary Art of Africa. Coevalness in the Global World in The Global Art World, 116-134. 
- precisely within the state of elective institutions. It is the markets, not people, that shape it and the markets seem not to be under any control, certainly not the democratic one. In short, citizens lost control over the economy. The path the nationalists dreamed of, which implies turning one's back to globalisation, is unfeasible. We need something that was called here politeia. But to make such a constitution effective in guaranteeing control to citizens, it has to be global. The above-mentioned authors believe that art has enormous power to build global culture and shape attitudes of global democracy; art which addresses political issues and which is characterised by global agoraphilia, willingness to be engaged globally, art which appears at the above enlisted exhibitions and biennials may be the avant-garde of such social and political changes. Obviously, excessive expectations for the causative function of art may be almost naive. Rasheed Araeen warns us against such illusions but he still maintains that criticism should be accompanied by the positive vision of the future, the vision of liberation ${ }^{53}$. Whereas Krzysztof Wodiczko adds: "After post-structuralism the time has come for self-reconstruction - the road to new visions and political, social and cultural constructs. Contriving and designing new, activating, open and agonistic projects [...] must become a part of this emancipatory programme"54.

The most recent example of such a tendency may be the seventh edition of the Berlin Biennial curated by one of the most world famous artists of global agoraphilia, Artur Żmijewski, under the meaningful title Forget Fear ${ }^{55}$. In a very interesting manner, Żmijewski shifted emphasis from the artwork to the art institution, turning the hierarchy established by artists in the late 196os upside down. They revolted against the dominant role of galleries and museums, protecting the work of art and its artistic nature from the manipulatory - as they declared - practices of these institutions. Żmijewski no longer perceives the work of art as a priority; politics - important to artists around 1968 as well - does not need mediation of art - it may be exposed in direct actions. Hence, art ceases to be of the fundamental importance and gives way to the directly formulated political action. There were several examples as such at the above-mentioned biennial, starting with the basement - nomen omen-occupied by representatives of the "occupy" movement, through Marina

53 Rasheed Araeen, A New Beginning. Beyond Post-colonial Cultural Theory and Identity Politics in The 'Third Text' Reader, 345.

54 Krzysztof Wodiczko, „Miejsce Pamięci Ofiar 11 Września (Propozycja przekształcenia Nowego Jorku w "miejsce ucieczki")", Artium Quaestiones XIX (2008), 280.

55 Artur Żmijewski, Forget Fear, ed. Artur Żmijewski, Joanna Warsza (Berlin: 7th Berlin Biennale for Contemporary Art, 2012). Some texts are available in Polish in "Nie lękajcie się", Krytyka Polityczna 30 (2012). 
Naprushkina's Focus Belarus, or Breaking News - rooms where films presenting various political actions were shown, to the so-called congress of terrorists (New World Summit) with participation of representatives (usually lawyers) of diverse organisations considered by the EU and the US as terrorist - the latter presenting during sessions schematic thinking typical of Euro-American services and politicians who lump together all actions (including charity) organised by people accused of collaboration with terrorists (for instance, organising hospitals in the Gaza Strip). Hence, the art institution (Biennale) was politically instrumentalised and deprived of its autonomy; its prestige and symbolic capital was used to publicise political problems of the alter-globalist character. In reality, Żmijewski understood that the mentioned "congress of terrorists" could not have happened in "normal" conditions - a Dutch artist Jonas Staal who organised it, applied a specific license attributed to artistic institutions which "are allowed to do more"; on the occasion of the biennial, he could give topics touched upon at the event more publicity than it would have been done by commentaries published in the mass media.

\section{Conclusion}

I have no doubts that post-communist agoraphilia - an attitude represented by critical artists both in Poland and in other countries of the former Eastern Bloc - was very successful in this matter ${ }^{56}$. Conflicts related with the body, religious iconography, nationalisms, etc., being the effect of rightwing circles' sharp reaction to critical art, showed how much power an artist may have in the struggle with a politician. The same strategy would be possible outside the borders of the national state, or even outside the area of a given region, hence in the global scale. The reflection upon art, presenting the profile of global agoraphilia, in consequence: art history interested in perceiving the artistic output of the past, may play a significant role in this field.

I do not claim that such beliefs will not face criticism ${ }^{57}$. What is more, in the same events which the above-mentioned authors perceive as a rebellion

56 Piotr Piotrowski, Agorafilia. Sztuka i demokracja w postkomunistycznej Europie (Poznań: Rebis, 2010), English edition: Art and Democracy in Post-Communist Europe (London: Reaktion, 2012).

57 In this context, there is a very interesting polemic of George Beker with the earlier mentioned article by Okwui Enwezor. Beker accuses the Documenta 11's author of diminishing the tension between the "public sphere" and "spectacle", failing to see the possibility to establish a strategy which would embrace both these spheres. First of all, however, Beker has doubts about the public. He claims that "great exhibitions" are "for nobody"; they are directed to the art world (so to themselves) rather than to the public who are supposed to take up their "counter-hegemonic" message: George Beker, The Globalization of the False: A Response to Okwui Enwezor in The Biennale Reader, 446-453. 
against the Western hegemony in the art world, others - like Joaquin Barriendos - observe the processes of re-westernisation of the world art culture. What the author sees in so-called geo-aesthetics, i.e. the interest of Western institutions in creative output from other regions of the world (he points to Latin America), is first of all the strategy of labelling the "other" in order to maintain the dominant role of the Western canon of artistic values. The author claims that the question which should be posed here in order to disclose the truth about the relations between "us" and "others" is the question about who and where decides about the attribution of the status of periphery. According to him - mainly Western institutions such as museums, above all. He notices the possibility to rebuild this relation but this would require a different museum policy of purchases, the willingness of museums to open their "imagination" to real problems of another culture. Most importantly, however, it would require something he calls the "inter-epistemological dialogue"58 which, I believe, may be the task not necessarily of art itself but art history. Assuming that the two are linked with each other systemically ${ }^{59}$, i.e. they are parts of the alter-globalist system, I can only summarise it by paraphrasing Kitty Zijlmans, quoted at the beginning of this text, that there is not (yet) alter-globalist art history. This does not mean, however, that it will not occur in the future...

Translation: Marta Skotnicka

58 Joaquín Barriendos, Geopolitics of Global Art: The Reinvitation of Latin America as a Geoaesthetic Region in The Global Art World, 98-114.

59 Kitty Zijlmans, The Discourse on Contemporary Art and the Globalization of the Art System in World Art Studies: Exploring Concepts and Approaches, 135-150.

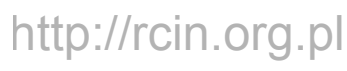

